Pamiętnik Literacki 2017, 1, s. 165-186
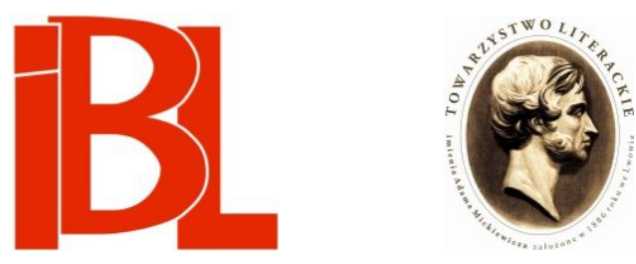

\title{
Listy Józefa Wittlina do Czesława Miłosza
}

oprac. Ryszard Zajączkowski 
Pamiętnik Literacki CVIII, 2017, z. 1, PL ISSN 0031-0514

\title{
LISTY JÓZEFA WITTLINA DO CZESŁAWA MIŁOSZA
}

\author{
Opracował \\ RYSZARD ZAJACZKOWSKI Katolicki Uniwersytet Lubelski Jana Pawła II
}

Czesław Miłosz i Józef Wittlin to dwie wielkie postaci emigracji. Duża liczba publikacji o każdym $z$ nich nie może przysłonić faktu, że ich wzajemne relacje nie zostały dotychczas dokładniej opisane. Wiedzę na ten temat daje m.in. korespondencja obu twórców. Listy Miłosza do Wittlina zostały już ogłoszone ${ }^{1}$. Uzasadnionym uzupełnieniem jest więc wydanie korespondencji autora Soli ziemi.

Prawdopodobnie w okresie II Rzeczpospolitej obaj pisarze nigdy się w Polsce nie spotkali, choć trudno przypuszczać, aby nie mieli o sobie żadnych informacji, gdyż byli wówczas dość znani. Nie zachowały się dokumenty sprzed wojny, które mogłyby dowodzić ich kontaktów (archiwum Wittlina spłonęło w jego warszawskim mieszkaniu na początku wojny). Wiemy tylko z pewnością, że widzieli się w Ameryce. Jako pierwszy za ocean wyruszył Wittlin, który opuścił Polskę w czerwcu 1939, udając się na stypendium do miejsca spotkań i pracy pisarzy w Royaumont pod Paryżem² . Tam zastała go wiadomość o wybuchu wojny. W maju 1940 dzięki usilnym staraniom połączył się we Francji z żoną i córką, a w czerwcu cała rodzina bezskutecznie próbowała zaokrętować się na statek odpływający do Anglii. Fiasko tego przedsięwzięcia stało się punktem zwrotnym w życiu Wittlinów i początkiem ich półrocznej włóczęgi po Europie. Żyli z honorariów, jakie pisarz otrzymywał od zachodnich wydawnictw za publikację Soli ziemi, a częściowo z pomocy charytatywnej (Stanisław Kot zostawił im wtedy sporą sumę pieniędzy). Najpierw z Saint-Jean-de-Luz pojechali do Lourdes (była to wówczas baza przerzutowa Polaków do Hiszpanii, skąd próbowali przedostać się do wojsk polskich na Zachodzie lub wyjechać z Europy). Następnie w sierpniu dotarli do Nicei na zaproszenie dalekiej kuzynki Wittlina ${ }^{3}$, która w tym francuskim kurorcie prowadziła pensjonat (Villa Mirabeille przy Avenue de Mirabeau 14) ${ }^{4}$. Znajdowała się tam też spora grupa Polaków poszukujących możliwości wyjazdu z Francji. Wittlin był gotów nawet zostać w tym miejscu, ale za namową dyplomaty, ministra Ignacego Matuszewskiego, oraz - przede wszystkim - Kazimierza Wierzyńskiego i Hermanna Kestena ${ }^{5}$ zdecydował się na dalszą podróż. Dzięki tzw. l'ordre militaire, czyli rozkazowi umożliwiającemu wyjazd do Vichy, zdobył

1 Cz. Miłos z, Listy do Józefa Wittlina. „Zeszyty Literackie” 2001, nr 3, s. 126-138.

2 Bezpośrednim powodem wyjazdu Wittlina $z$ Polski była nagonka w prasie endeckiej na niego oraz na Tuwima i Słonimskiego.

3 Nie udało się ustalić nazwiska owej kuzynki.

4 O niektórych szczegółach pobytu Wittlinów we Francji w 1940 r. pisze E. Wittlin-Lipt on (Z dnia na dzień. Reportaż z moda w tle z czasów zawieruchy. Przeł. L. M a c Milla n. Toruń 2012, s. 121-164).

$5 \quad$ Hermann Kesten (1900-1996) był pisarzem niemieckim, którego Wittlin poznał pod koniec lat dwudziestych XX w. w Berlinie. Od tego czasu popularyzował jego twórczość w Polsce, Kesten zaś pomagał zaistnieć Wittlinowi w Niemczech. Niektóre informacje na ten temat podaję w artykule Literatura i życie. O wspótpracy Józefa Wittlina z Walterem Landauerem i o tłumaczeniach „Soli ziemi” („Pamiętnik Literacki” 2016, z. 1). 
dokumenty wymagane przy opuszczeniu Francji. Potem, w obawie przed wcieleniem do obozu pracy, krótko ukrywał się w angielskim szpitalu w Marsylii, a wreszcie dzięki otrzymaniu prawa pobytu w Chinach Wittlinowie dostali wizy tranzytowe do Portugalii 6 . W listopadzie 1940 wyruszyli pociągiem z Nicei do Tuluzy, następnie zaś przez Lourdes i Biarritz dotarli do hiszpańskiej granicy, którą przekroczyli $4 \mathrm{X}^{7}$.

Po tygodniowym pobycie w stolicy Hiszpanii Wittlinowie udali się do Lizbony, gdzie przybyli 31 X. Zaczęło się wówczas oczekiwanie na wizę amerykańską. Do tego doszła choroba córki, a nawet jej hospitalizacja z powodu operacji wyrostka. W tym okresie dużą pomoc okazywał im Kesten. To on właśnie wystarał się o umieszczenie nazwiska Wittlina na liście Thomasa Manna $\mathrm{z}$ ramienia American Rescue Committee. Organizacja ta wysyłała gwarancje zaopiekowania się uchodźcami i udzielała im wsparcia. Dzięki zapobiegliwości niemieckiego pisarza Wittlinowie mogli emigrować do USA. 17 I 1941 odpłynęli z Lizbony, a pod koniec miesiąca po trudnej podróży przybyli do Nowego Jorku. Tam zajęli się nimi Kestenowie oraz osoby związane $z$ nowojorska prasa polonijną, jak choćby biznesmen i wydawca „Nowego Świata” Maksymilian Węgrzynek czy Szymon Kamiński, redaktor „Robotnika”. Istotne było też stypendium rządu londyńskiego wypłacane przez Polish Information Center. Już 5 II powitalny list do Wittlina wystosował Arthur P. Coleman, pierwszy rodowity amerykański slawista, który później dbał o jego zaistnienie w nowym otoczeniu. Wraz z przybyciem do Stanów Zjednoczonych Wittlin wszedł w elitarne środowisko polskich i zagranicznych literatów, ludzi kultury i polityki ${ }^{8}$, ponieważ - jak zauważył Miłosz:

W czasie wojny znaleźli się [...] [w amerykańskiej metropolii] liczni pisarze i artyści języka niemieckiego z Austrii, Wegier i Niemiec. Było to bardzo specyficzne środowisko, jakby dalszy ciag monarchii habsburskiej i Niemiec weimarskich, z takimi nazwiskami, jak: Hermann Broch, autor Śmierci Wergilego, czy Bela Bartok ${ }^{9}$.

Wittlin brał udział w wieczorach autorskich, imprezach literackich i spotkaniach z Polonią. Na łamach prasy polonijnej ogłaszał też teksty publicystyczne i poetyckie. Jedno z pierwszych publicznych wystapień pisarza, reklamowanego w „Nowym Świecie” jako „oficjalny polski kandydat do Nagrody Nobla” (za opublikowaną w 1936 r. Sól ziemi, która jeszcze przed wojną została przetłumaczona na 13 języków), miało miejsce 25 II 1941 w Kole Polskim w Nowym Jorku10. W latach 1941-1942 Wittlin był redaktorem „Tygodniowego Przeglądu Koła Pisarzy z Polski”, od r. 1943 do 1947 zaś redagował „Tygodnik Polski”. W roku 1943 otrzymał nagrody Amerykańskiej Akademii Sztuki i Literatury oraz Narodowego Instytutu Sztuki i Literatury w Nowym Jorku za amerykańskie wydanie Soli ziemi.

Mimo pierwszych sukcesów sytuacja pisarza i jego rodziny była jednak trudna. Wittlin sporo chorował, co powodowało, że nie mógł zarabiać. Dorywcze zajęcia podejmowała jego żona, lecz ich warunki życiowe $z$ roku na rok ulegały pogorszeniu, o czym świadcza listy pisarza do Mieczysława Grydzewskiego, Kazimierza Wierzyńskiego, Juliana Tuwima czy Manfreda Kridla. Paradoksalnie - sytuacji nie poprawiło nawet zakończenie wojny, ponieważ

6 Pomocny w tym okazał się Adolf Kon, nb. postać dość tajemnicza, Honorowy Konsul Haiti, posługujący się również kilkoma innymi nazwiskami i tytułami.

7 Zob. „Mój ojciec żył pisaniem, ono go pochłaniało”. Z E. Wittlin-Lipton rozmawia W. S. W o cła w. W zb.: Etapy Józefa Wittlina. Red. W. Li gę z a, W. S. W o cł a w. Kraków 2014, s. 242.

8 Zob. N. Ta y lor - T e rl e c ka, Józefa Wittlina pierwsze kroki na Nowym Kontynencie. W zb.: Literatura polska obu Ameryk. Studia i szkice. Seria 1. Red. B. Now a cka, B. Sza ł a s ta-Rogows k a. Katowice-Toronto 2014.

9 Cz. Miło s z, Mój Wittlin. „Dekada Literacka” 2001, nr 5/6, s. 75.

10 Siedziba Koła Polskiego mieściła się w Konsulacie Generalnym RP w Nowym Jorku pod adresem 151 E 67 St. 
dla polskich wygnańców takich jak Wittlin oznaczało ono cofnięcie zasiłków rządu londyńskiego. Jako realna pojawiła się natomiast możliwość powrotu do kraju. Dylemat: czy pozostać w Ameryce, czy powrócić do Polski, był trudny do rozstrzygnięcia m.in. z powodu zaproszeń kierowanych do Wittlina z kraju. Propozycje takie składali mu choćby Stanisław Ryszard Dobrowolski, Jarosław Iwaszkiewicz i Aleksander Wat, którzy chcieli pozyskać go do pracy w „Nowinach Literackich” oraz w „Odrodzeniu”. Za opuszczeniem Ameryki przemawiał też potęgujący się zły stan zdrowia (dodatkowe problemy neurologiczne) i związana $\mathrm{z}$ tym niepewność co do możliwości zarobkowania. Nic więc dziwnego, że w liście do Hermanna Brocha (z 14 IX 1948) ${ }^{11}$ Wittlin wspominał o planach wyjazdu do Polski w październiku 1948. Wszakże pod koniec r. 1948 przyjął obywatelstwo amerykańskie ${ }^{12}$. Dokonał tego jednak w poczuciu wielkiego rozdarcia, jak zauważył w liście do Wierzyńskiego z 1 XII 1948: „Obczyzna mi nie służy, a co do ojczyzny zaczynam już tracić nadzieje”" ${ }^{13}$. Na początku $1949 \mathrm{r}$. dla Wittlina było jasne, iż do Polski nie powróci. Na jego decyzję o pozostaniu w Ameryce miały wpływ różne czynniki. Istotne było choćby to, że na emigracji mógł zachować wolność słowa i niezależność od nacisków politycznych. Nie powinno zatem dziwić, że niecałe trzy lata później namawiał Miłosza, aby zamieszkał na stałe w Ameryce, argumentując to tym, iż wielu pisarzy odrodziło się, przebywając poza krajem ${ }^{14}$.

W roku 1946, dokładnie 28 I, do Ameryki przypłynął Miłosz, który miał objąć stanowisko referenta kulturalno-prasowego w konsulacie polskim w Nowym Jorku. W związku ze swoją działalnościa poszukiwał kontaktów wśród emigrantów z Polski. Jednakże grono znajomych, których miał po przyjeździe, było bardzo wąskie: „Doktor Berlstein, [Aniela i Lucjan] Borowikowie, socjolog Aleksander Hertz, Józef Wittlin, Aleksander Janta-Połczyń-

11 Listy J. Wittlin a do H. Brocha znajdują się w archiwum Brocha w Beinecke Library. Przez ostatnie lata życia Broch był profesorem w Yale.

12 J. Wittli n rozważał to już wcześniej, choć bez entuzjazmu, o czym pisał 16 V 1946 do M. Grydzewskiego (Listy do redaktorów „Wiadomości”. Oprac. J. Ole j n i c za k. Konsultacja edytorska B. Dorosz. Toruń 2014, s. 36): „Albo przyjmę obywatelstwo amerykańskie i będę się tutaj, na stare lata, męczył wśród najbardziej obojętnego i okrutnego środowiska, w jakim kiedykolwiek żyłem, starając się o wniknięcie w to środowisko, albo będę musiał wracać. Białym emigrantem nie mam zamiaru zostać. Nie mogąc skutecznie przyczynić się do wolności naszego kraju, pragnę zachować moją własną, prywatną wolność, o co tutaj rzeczywiście nietrudno, chociaż nędzarz naprawdę nigdzie nie jest wolny. Moja żona od jesieni na próżno zabiega o pracę, była parę dni w fabryce trykotaży, pisała listy w jakimś biurze handlowym, ale za powoli na tutejsze tempo". Z kolei H. Wittlin w wywiadzie z A. Frajli c h-Zaj a c zatytułowanym Skamandryci w Nowym Jorku (maszynopis został mi udostępniony przez A. Frajlich-Zając) tak opisywała decyzję Wittlina o pozostaniu w Ameryce:

„H. W.: [...] punktem głównym, kiedy on się zdecydował, że nie wróci do Polski, do PRL - to było tłumaczenie Hiroshimy - jedyna książka, która posłał. Przetłumaczył Herseya Hiroshimę i napisał do tego przedmowę. Ta przedmowa jest włączona do Orfeusza.

A. F. Z.: A w którym roku to było?

H. W.: Gdzieś w 46-tym, 47-ym... I tam zdjęli tę przedmowę i dali jakiegoś kretyna, który napisał kretynizmy. Mój mąż się na wszystko zgadzał, ale nie na zmiany tekstu. No i oczywiście bez zmian tekstu było trudno pomyśleć, żeby można było coś w tym czasie wydać, prawda? [...] Wreszcie pojechał do Polski jeden z konsulów tutejszych, który też już nie żyje. Był naszym przyjacielem. I on powiedział: "Panie Józefie, to nie dla pana, pan tam nie wytrzyma pięciu minut. Tam jest takie napięcie nerwów". Natomiast do powrotu bardzo namawiał Wittlina J. Tu wi m (list do J. Wittlina z Toronto, z 31 VII 1945. W: B. D or o s z, Lechoń i Tuwim-dzieje trudnej przyjaźni. Warszawa 2004, s. 149-151).

13 Listy J. Wittli n a do K. Wierzyńskiego przechowywane są w Bibl. Polskiej w Londynie (Archiwum K. Wierzyńskiego).

14 J. Wittlin, list do Cz. Miłosza, z 16 VII 1951. Beinecke Library. Archiwum Cz. Miłosza. 
ski, oto mniej więcej mój Nowy Jork lat 1946-1950" - wspominał po latach ${ }^{15}$. Oczywiście, lista Polaków znanych poecie była dłuższa, ale nie imponująca. Najbliższym „polskim” zapleczem w Nowym Jorku stali się dla niego (i przybyłej z nim żony) żydowscy inteligenci, którym udało się dotrzeć do Ameryki na początku wojny, a także ludzie podzielający jego ocenę sytuacji politycznej w Europie oraz znajomi $z$ Wilna ${ }^{16}$. Miłosz poznał też polskich duchownych pracujących wśród Polonii i nawiązał kontakt z dość aktywnie działającym Klubem Polskim przy Uniwersytecie Columbia. Ogólnie jednak biorąc poszerzaniu znajomości nie sprzyjały ani podejrzliwość personelu w nowojorskim konsulacie, a później w ambasadzie, ani nawał obowiązków młodego urzędnika. Nieufnością wobec dyplomacji rządu warszawskiego odznaczała się też postawa Polonusów - zwłaszcza tych, którzy przybyli do USA po wojnie.

W porównaniu z Wittlinem sytuacja Miłosza przedstawiała się lepiej: był on młodszy, miał stabilną posadę i wykazywał dużo aktywności w swej pracy. Główne jego zadanie stanowiła popularyzacja kultury polskiej w Stanach Zjednoczonych. Dlatego poeta sporo podróżował, nawiązywał kontakty z galeriami i muzeami, organizował wystawy, wygłaszał prelekcje, pisał artykuły do periodyków amerykańskich i polskich. $Z$ czasem coraz lepiej poruszał się w wielorasowym i wieloetnicznym środowisku. Doskonalił też znajomość języka angielskiego i brał udział w amerykańskim życiu literackim ${ }^{17}$. Nie oznaczało to jednak, że był zafascynowany Ameryką. Wprost przeciwnie - podobnie jak Wittlin nie lubił jej, nie podobała mu się brzydota otoczenia i nieznośność klimatu, ale musiał zaakceptować istniejące niedogodności. Dlatego w połowie 1946 r. mógł stwierdzić: „Przyzwyczailiśmy się już do Ameryki, co polega na zdaniu sobie sprawy, że dla Europejczyka w pewnym wieku jest to kraj, do którego nie można się przyzwyczaić"18. Podobieństwo spojrzenia na Amerykę w przypadku obu pisarzy zauważył Iwaszkiewicz w liście do Miłosza:

Jednocześnie z Twoim miałem wielki list od Wittlina, zabawne, jak Wasze sądy o Ameryce są zbieżne. To chyba musi właśnie tak być, bo w entuzjazmy Horzycy i dawnego Kazia Wierzyńskiego nie wierzę ${ }^{19}$.

Wittlin i Miłosz poznali się zatem w 1946 r. w Nowym Jorku, jeszcze przed wyjazdem tego ostatniego do pracy w ambasadzie polskiej w Waszyngtonie w listopadzie 1946. W sprawozdaniu pisanym dla Ministerstwa Spraw Zagranicznych Miłosz w następujący sposób charakteryzował Wittlina:

Józef Wittlin: Na Wittlinie, podobnie jak na wszystkich inteligentniejszych ludziach emigracji, ogromne wrażenie zrobiły pisma literackie wydawane w Polsce. Przyznaje im wysoki poziom i jest bardzo zainteresowany pracami działających w kraju pisarzy. Wyraził chęć posyłania do pism krakowskich swoich utworów. Jest jednak pełen obaw i zahamowań. Politycznie nie jest zdecydowany $-z$ jednej strony związany był dotychczas z grupa Lechonia, $z$ drugiej jednak ocenia w zupełności pozytywnie wyniki osiagnięte w kraju. Jest przy tym w istocie człowiekiem o przekonaniach szczerze demokratycznych ${ }^{20}$.

Od czasu przeniesienia się Miłosza do Waszyngtonu kontakty obu pisarzy były praw-

Cz. Miłos z, Abecadło. Kraków 1997, s. 71.

Zob. E. Kołodzi ej czyk, Amerykańskie powojnie Czesława Miłosza. Warszawa 2015, s. 33. A. Fr a na s ze k, Miłosz. Biografia. Kraków 2011, s. 421-422.

Zob. Kołodziejczyk, op. cit., s. 31-56.

Cz. Miłosz, list do T. Brezy, z 23 VIII 1946. W: Zaraz po wojnie. Korespondencja z pisarzami 1945-1950. Kraków 2007, s. 531.

J. I wa s z ki ew ic z, list do Cz. Miłosza, z 22 VII 1947. W: jw., s. 180.

Sprawozdanie z czynności za czas od 7 II - 30 III 1946 z działu kultury i sztuki - radca Czesław Mitosz. Archiwum MSZ, z. 21, w. 87, t. 1186. Cyt. za: Fr a n a s z e k, op. cit., s. 421-422. 
dopodobnie rzadsze, ale zarazem otwierały się nowe możliwości współpracy. Z okazji 150 rocznicy urodzin autora Pana Tadeusza pojawił się pomysł wydania tzw. księgi mickiewiczowskiej. Idea tej publikacji wyszła $z$ ambasady polskiej, która też finansowała projekt. $Z$ pewnościa jednym $z$ głównych pomysłodawców tego przedsięwzięcia był Miłosz, który w liście $\mathrm{z}$ kwietnia 1948 zwracał się do swego wileńskiego profesora Manfreda Kridla (kierującego od niedawna katedrą literatury polskiej im. Adama Mickiewicza na Uniwersytecie Columbia), aby zajął się redakcją i przygotowaniem książki „wprowadzającej cudzoziemców w Mickiewicza”. Szczegóły na temat rozpoczętych wówczas prac zawiera korespondencja Miłosza kierowana do Kridla ${ }^{21}$. Współredagowanie publikacji zaproponowano wkrótce Wittlinowi, mającemu już doświadczenie w tego rodzaju aktywności, gdyż w $1943 \mathrm{r}$. wraz z Kridlem i Władysławem Malinowskim przygotował on antologię polskiej myśli demokratycznej For Your Freedom and Ours. Democratic Heritage in Poland (New York 1943), do której napisał Epilog, odważnie zwalczając amerykańskie stereotypy o Polakach (np. zarzut antysemityzmu). W innej publikacji, The Torch of Freedom. Twenty Exiles of History (New York 1943) zamieścił też szkic o Kościuszce 22 oraz pisał artykuły do „Saturday Review” (1942, nr 4; 1947, nr 24) i do „Books Abroad”23. W rezultacie podjętych prac ukazała się w 1951 r. w Nowym Jorku, pod redakcją Kridla, książka Adam Mickiewicz. Poet of Poland. A Symposium. Prezentowała ona polskiego wieszcza $\mathrm{z}$ perspektywy międzynarodowej, i to nie tylko jako poetę, lecz także jako myśliciela i publicystę politycznego. Istotnym wątkiem tej publikacji było również przedstawienie go na tle stosunków polsko-żydowskich. Wśród autorów artykułów znaleźli się m.in. badacze tej miary co Wacław Borowy, Czesław Zgorzelski czy nestor amerykańskiej slawistyki, Georg Rapall Noyes. Z tego okresu datują się też częste kontakty Wittlina i Miłosza. Ten ostatni wizytę u Wittlina opisywał w liście do Iwaszkiewicza z 22 X 1949:

Siedziałem długo u Wittlina, tam, gdzie mieszka, jest ślicznie, a szczególnie teraz, kiedy lasy są żółte. $Z$ okien widać wielką dolinę pełną lasów - i Brodway, ale to sam północny koniuszek Brodwayu, z 10 czy 15 mil od centrum. Wittlin czytał mi fragmenty nowej poprawionej wersji Odysei, nad która pracuje. To bardzo piękny i jednak epokowy przekład, bo ten Homer pseudoklasyczny, jaki poza tym jest po polsku, zupełnie nieznośny. Wittlin jest pełen planów pisarskich i znalazłem go tym razem w dobrej formie. Zresztą mieliśmy dużo do gadania o Mickiewiczu, bo katedra im. Mickiewicza przy Columbia przygotowuje księgę po angielsku o Mickiewiczu²4.

W latach późniejszych kontakty obu pisarzy chyba nieco osłabły, a w każdym razie nie zostały zaświadczone w korespondencji. Wiadomo jednak, że obaj wzajemnie cenili swoje utwory, czemu dawali wyraz w listach nie tylko do siebie, lecz także do innych osób - choćby do Giedroycia. Czy jednak się lubili? Na ten temat można mieć różne opinie. Stosunek Miłosza do Wittlina opisywała Elżbieta Wittlin-Lipton w rozmowie z Wojciechem Wocławem:

Miłosz uważał, że mój ojciec nigdy nie będzie wielki, że nic ważnego już nie zdoła napisać. Mówił o tym ciotce Wiktorii Winnickiej, znanej też jako Wikta, z którą był bardzo blisko w Kalifornii.

$[\ldots]$

Cz. M ił o s z, „Mój wileński opiekun”. Listy do Manfreda Kridla (1946-1955). Z uzupetnieniem o listy Manfreda Kridla $i$ addendum. $Z$ autografu do druku przygotował, słowem wstępnym, przypisami i notą edytorską opatrzył A. Ka r c z. Toruń 2005.

22 Polską wersję opublikowano w r. 1944 w wydawanym w Londynie miesięczniku „Nowa Polska”.

23 Joseph Wittlin by Wittlin. „Books Abroad” 1942, Winter. W późniejszym czasie na łamach tego pisma J. Wit t l in popularyzował literature polską: A Quarter Century of Polish Literature (1927-1952). Jw., 1956, nr 1; Polish Literature: A Post Scriptum. Jw., nr 2. 
Kiedy [Miłosz] przyjechał do Ameryki po raz pierwszy, [...] spędził u nas kilka dni. Próbował wtedy namówić ojca na powrót do Warszawy, powołując się na poczucie patriotyzmu. Ojciec powiedział mu wtedy, że nie będzie popierać rządu, który „stał pod drugiej stronie Wisły”, kiedy Warszawa paliła się podczas powstania. Miłosz obraził się na mojego ojca, a potem nawet trochę się nad nim znęcał. Nie tolerował depresji ani choroby, lubił odgrywać supermana. Przecież ojciec nie wstawał o siódmej rano i nie siadał od razu do pracy, za to Miłosz zachowywał szaloną dyscyplinę. Ojciec przez całe życie pozostawał perfekcjonistą, chciał z siebie dać jak najwięcej, ale miewał również okresy ciężkiej depresji. Wtedy po prostu nie mógł pisać. Miłosz traktował go jak przegranego ${ }^{25}$.

Swoje wspomnienia o Wittlinie zawarł Miłosz w znanym eseju Mój Wittlin, w którym odnosząc się do swego starszego kolegi przyznał m.in., że „szczupłość jego dorobku nie umniejsza wagi jego osiagnięć” ${ }^{26}$. A co myślał Wittlin o Miłoszu? Autor Soli ziemi wielu swoich opinii nie wypowiadał głośno, lecz zostawił je w nieopublikowanych notatnikach, prowadzonych przez prawie pół wieku ${ }^{27}$. Zawierają one najróżniejsze zapiski, które miały być pomocne w codziennym życiu, ale również służyć jako materiał literacki czy relacje dla potomnych. W tych tekstach, których Wittlin nie zamierzał publikować, są przynajmniej trzy wzmianki o Miłoszu. W notatniku rozpoczętym 9 XII 1957 autor zapisał: „C. Miłosz. Jest jednocześnie gwiazdą i astronomem wpatrzonym w tę gwiazdę” (t. 11, n. 116, k. 258; 1957). Z kolei w notesie prowadzonym od 20 II 1960 czytamy: „Miłosz i jego stosunek do ludzi. Świadczyłem mu wiele uprzejmości. A on nie. Czy można żądać od słońca, żeby się rewanżowało za adorację" (t. 11, n. 120, k. 474; 1960). I wreszcie pod koniec tego samego notesu Wittlin pozostawił krótki zapis: „Cz. M. - szlachcic z plebejską duszą” (t. 11, n. 120, k. 480; 1960).

Przedstawiona kolekcja listów ${ }^{28}$ pochodzi $\mathrm{z}$ archiwum Czesława Miłosza w Beinecke Library w New Haven (USA). Na tle innych kolekcji nie jest ona obszerna. Można przypuszczać, że wynika to $\mathrm{z}$ trzech powodów: do kontaktu obu pisarzy dochodziło często drogą telefoniczną; nie byli oni sobie zbyt bliscy; część listów zaginęła (lub została zniszczona). Jeśli porównać listy Wittlina do Miłosza z korespondencją tego pierwszego kierowaną do Kridla, Wierzyńskiego, Haupta czy Janty-Połczyńskiego (wszystkie te zbiory pozostaja jeszcze w archiwach), należy stwierdzić, że listy do Miłosza są stosunkowo najbardziej oficjalne i oszczędne w przedstawianiu realiów życia na obczyźnie: Wittlin nie pisze dużo o sobie, o swoich problemach i planach literackich. Jednak zestawione $z$ opublikowanymi już listami Miłosza do Wittlina składają się na ważny ślad kontaktów i współpracy obu pisarzy z pewnością eminentnych przedstawicieli polskiej literatury i znaczących postaci naszej emigracji.

W publikowanych tu listach, ułożonych w porządku chronologicznym, zmodernizowano pisownię oraz interpunkcję, zachowując jednakże niektóre charakterystyczne cechy, jak np. myślniki, stosowane przez Wittlina zbyt często i nie zawsze właściwie. Ujednolicono wcięcia akapitowe oraz układ nagłówków, dat i podpisów.

„Mój ojciec żyt pisaniem, ono go pochłaniało”, s. 245.

Miłosz, Mój Wittlin, s. 76.

Są to 134 kieszonkowe notatniki. Wittlin dokonywał w nich zapisków od początku lat dwudziestych prawie do końca lat sześćdziesiątych XX wieku. Obecnie są zdeponowane w 12 teczkach w Muzeum Literatury im. Adama Mickiewicza w Warszawie, sygn. 1701. Lokalizując cytaty z tych notatników, podaję kolejno: numer teczki, numer notatnika, numer karty, na której zapisano wypowiedź, oraz, po średniku, rok, $z$ którego pochodzi zapis.

Za pomoc w przepisywaniu listów J. Wittlina dziękuję pani dr Ewie Wi elgos z. 
5400 Fieldston Road

New York 63, N.Y.

13 marca 1947

Wielce Szanowny i Drogi Kolego!

Bardzo dziękuję za list ${ }^{1}$, choć taki lakoniczny i mało donoszący o tym, co się z Państwem dzieje. Słyszałem, że wyjeżdżał Pan gdzieś na odczyty czy do Kridla²? Bardzo mi tutaj brak Pana. Cieszyłbym się, gdyby Pan kiedyś do mnie zajrzał. Jest to egoizm z mojej strony, gdyż Pańskie miłe wizyty są dla mnie tonicum, a nie śmiałbym sądzić, iż i ja tak samo na Pana oddziaływam. Ostatnio prowadzę ożywioną korespondencję $z$ kolegami w kraju. Odezwał się Dobrowolski, choć ani słowem nie wspomniał o sprawach, na które powinien był mi odpowiedzieć ${ }^{3}$. Razem z Iwaszkiewiczem zapraszają mnie do współpracy w nowym piśmie „Nowiny Literackie”. Na kopercie jest winietka, która łudząco przypomina winietke śp. „Wiadomości Literackich", i nie tylko to, bo i krój czcionek jest taki sam. Ogromnie wzruszył mnie Jarosław. Nazajutrz otrzymałem depeszę od Wata, również zapraszającą do stałej współpracy w warszawskim wydaniu „Odrodzenia”. Czy to krakowskie „Odrodzenie” przenosi się do Warszawy, czy też będzie wychodziło w obu miastach? Będę Panu wdzięczny, jeśli zechce mnie Pan poinformować na te tematy, o ile Panu więcej ode mnie wiadomo.

Łączę wiele serdecznych ukłonów, prosząc o życzliwą pamięć

Józef Wittlin [podpis odręczny]

Maszynopis na szarym papierze formatu A5. List wysłany 14 III 1947 na adres: Mr. Czesław Miłosz / 914 Sheridan Street / Washington, D.C.

1 Nie zachował się list Miłosza, na który odpowiedzią jest ten list Wittlina.

2 Manfred Kridl od 1940 r. przebywał na emigracji, głównie w Stanach Zjednoczonych, w 1948 r. objął katedrę im. Adama Mickiewicza na Uniwersytecie Columbia w Nowym Jorku.

3 Stanisław Ryszard Dobrowolski w latach 1947-1948 był zastępcą redaktora naczelnego „Nowin Literackich".

5400 Fieldston Road New York 63, N.Y. 9 listopada 1947

Szanowny i Drogi Panie Czesławie,

list Pański ${ }^{1}$ przyszedł tak bardzo à propos, że dziękuję zań i Panu, i Opatrzności. Dziękuję za życzliwą pamięć. Do moich kłopotów medycznych dołączył się ostatnio nowy, który zepchnął moją osobę na plan drugi. Moja żona musi, i to w najbliższym czasie, iść do szpitala i poddać się operacji. W środę sprawa się wyjaśni, bo będzie badana przez specjalistę w Medical Center. Jestem zaniepokojony, chociaż lekarka żony, dr Szuldberg, u której odbyło się przyjęcie (pamięta Pan?) po Pańskim odczy- 
cie w Public Library - twierdzi, że nie ma powodu do obaw. Ale żona zaniedbała swe niedomagania i teraz musi radykalnie pozbyć się ich przyczyny. Więc będę Panu niezmiernie zobowiązany za jak najszybszą pomoc. Szpital, nawet ogólna sala, testy, Roentgeny etc. - to są rzeczy b. kosztowne. Niestety, w tym kraju nie mam ubezpieczeń społecznych. Myślę, że odda nam Pan ogromną przysługę, przysyłając jakich 250 dolarów, z czego 100 byłoby dla mnie (zastrzyki ekstraktu wątroby, lekarstwa takie jak parafina, pawadryna ${ }^{2}$ etc., krótkie fale...), przepraszam za tę listę. Sam Pan wie, jakie to smutne i upokarzające. Ale przede wszystkim moja żona - ta sprawa jest bardzo pilna. Im wcześniejsza operacja - tym dla niej będzie lepiej. Dziękuję Panu z góry - za wszystko.

Jestem niezmiernie ciekaw Pańskiego poematu. Będę się cieszył, jeśli mi Pan prześle kopię. Proszę się nie zrażać zawartymi w nim złośliwościami i proszę się nie bać „przyszłości żółciowego satyryka”. Przecież nawet pół-święty Léon Bloy ${ }^{3}$ - był złośliwy i gorzki. Osobiście nie dowierzam w dzisiejszych czasach 100\%owym szlachetnikom i wznioślakom. To podejrzane figury. Istnieje tartufesja ${ }^{4} \mathrm{w}$ sztuce, może gorsza niż w życiu religijnym. To, czego się Pan obawia - jest wentylem dla duszy, że użyję tak niemodnego pojęcia. A co do Owidiusza, czy myśli Pan o Tomi (Hiems Tomitam $)^{5}$ ? A czy Pan wie, że koło Kut ${ }^{6}$, w moich huculskich stronach, pokazują rzekomy grób Owidiusza? Jeżeli tam był zesłany - to w niezwykle piękne i ciepłe strony. Bo tam zaczynała się Dacja, a Rzym zsyłał tam swoich political prisoners, ale także i criminals - z czego urósł - choć usprawiedliwiony przesąd, że wszyscy Rzymianie - to potomkowie kryminalistów.

Czytał Pan w jednym $z$ ostatnich numerów „Kuźnicy” bardzo wolne, ale bardzo - moim zdaniem - dobre przekłady Tuwima - Horacego ${ }^{7}$ ?

Słonimski nie bardzo się zmienił od czerwca 1940 r., kiedy go po raz ostatni widziałem. Trochę schudł, ale jest rześki i pełen energii. Bardzo się rozczuliłem po tylu latach jego wizyta.

Koresponduję z Pańskim wileńskim kolegą Zagórskim ${ }^{8}$ i załatwiam, w imieniu prof. Heintausen, lekarstwa dla jego żony.

Jak się ma Pańska rodzina? Kiedy będę miał zaszczyt poznania Pańskiego syna? ${ }^{9}$ Mam dla niego książkę - pięknie wydany przekład Wittlina - Pinokia z ilustracjami Witza ${ }^{10}$. Przysłali mi $z$ „Wiedzy”. Ale musi trochę jeszcze poczekać.

Ufam, że jak najlepiej Pan dla nas te sprawy załatwi, uwzględniając zwłaszcza sytuację mojej żony. Z góry dziękuję i przepraszam. Sprawa żony b a r d z o piln a!

Dla wszystkich Drogich Państwa łączę najserdeczniejsze pozdrowienia oddany Józef Wittlin

Rękopis na dwóch kartkach białego papieru formatu A4, atrament czarny. List wysłany 10 XI 1947 na adres: Mr. Czesław Miłosz / 914 Sheridan Street / Washington, D.C.

1 Nie zachował się list Miłosza, na który odpowiada tu Wittlin.

2 Prawdopodobnie chodzi o papawerynę - preparat stosowany w stanach skurczowych mięśni gładkich: przewodu pokarmowego, dróg żółciowych oraz dróg moczowych.

3 Léon Bloy (1846-1917) - francuski powieściopisarz, eseista, poeta o wyraźnej orientacji katolickiej.

4 „Tartufesja” 'zakłamanie' - neologizm Wittlina utworzony od nazwiska Tartuffe, głównego bohatera sztuki Moliera Świętoszek. 

pisał na wygnaniu w Tomi (obecnie Konstanca w Rumunii).

6 Chodzi o miejscowość Kuty, jedno z największych miast w powiecie kosowskim na Ukrainie, uważane za stolice południowo-wschodniej Huculszczyzny, której miłośnikiem i piewcą był Wittlin. Kuty leżą u stóp góry pod nazwą Owidiusz (pochodzi ona od słowa „owid” - horyzont, widok), gdzie według legendy został pochowany Owidiusz.

7 Wittlin ma na myśli tłumaczone przez J. Tuwima wiersze zawarte w: Hor a cy, Wybór poezji. Przeł., oprac. J. Zawirows ki. Kraków 1923. BN II 25.

Chodzi o poetę Jerzego Zagórskiego.

Mowa o pierworodnym synu Miłosza - Antonim (ur. 1947 r.).

Ignacy Witz (1919-1971) - polski malarz, rysownik, krytyk sztuki. Pinokio w przekładzie J. Wittli in a ukazał się po raz pierwszy w 1926 r. w wydawnictwie „Rój”. Następne edycje były w latach 1946, 1948, 1950, 1951. Dwa pierwsze powojenne polskie wydania Pinokia były opublikowane przez oficynę „Wiedza”, a kolejne przez „Książkę i Wiedze”.

5400 Fieldston Road New York 63, N.Y. 29 sierpnia $1949^{1}$

Drogi Panie Czesławie,

jak Pan znosi te upały? Ja - fatalnie. Na szczęście wyjeżdżam w tym tygodniu nareszcie na wieś, $z$ całą rodziną i kotami. Prof. Kridla nie ma w New Yorku. Będę $z$ końcem września $z$ powrotem $w$ domu i chciałbym bardzo, żebyśmy znów w trójkę, tj. z Panem i z profesorem, mogli odbyć końcowa pogawędkę redakcyjną, ustalić, jakie teksty z tych, które zebrałem, dać do tłumaczenia, itd. Niestety nie wszystko idzie tak, jak projektowaliśmy, co zresztą było do przewidzenia. Np. ani rusz nie mogę znaleźć kompetentnego autora do Emersona ${ }^{2}$. Co się tyczy Legionu żydowskiego, myślę, że najlepiej będzie zwrócić się do człowieka, który pierwszy, dwadzieścia lat temu, tę sprawę poruszył, a więc do Romana Brandstättera ${ }^{3}$. Będę Panu wdzięczny za jego adres. On jest gdzieś w Polsce. Znałem go jako żarliwego syjonistę, obecnie jest gorliwym katolikiem, tzn. był nim jakie dwa lata temu. Bo wiemy, jakie fluktuacje przechodzą wieszcze tam, gdzie wody są ruchome.

Proszę teraz Pana o następującą rzecz. Dużą przysługę oddał mi mój przyjaciel w Paryżu, malarz Ludwik Lille ${ }^{4}$. Porobił dla mnie fotostaty z Odyńca, tak, że będziemy mogli dać autentyczny opis wizyty Mick[iewicza] u Goethego. Przysłał mi też parę rzadkich książek, z których będziemy korzystali przy wyborze "głosów” o Mickiewiczu. Miał wydatki, chodził, krzątał się, zabiegał: myślę, że należałoby mu posłać jakich 25 dolarów, które w jego obecnej sytuacji bardzo mogą się przydać. Jak to zrobić, żeby miał te dolary i mógł sam sobie je w Paryżu zmienić? Proszę mi napisać, co Pan o tym sądzi. Jeżeli Pan mógłby mu przekazać wprost na jakiś bank w Paryżu, adres jego jest następujący:

Ludwik Lille

51, Bd. St. Ja[c]ques

Paris XIVe

[Dopisek odręczny:] Oddał naprawdę konkretną przysługę. 
Czytał Pan ostatnia „Kulturę”? Znalazłem tam monstrualne dziecko powstałe ze skrzyżowania Pańskiego Toastu z Traktatem moralnym. To piła Przyłuskiego ${ }^{5}$. "Coś” nie wyszło - jak by powiedziała Kalinówna ${ }^{6}$. Co mi Pan nowego przyśle do czytania? ${ }^{7}$ Jak się ma Szan[owna] rodzina?

Proszę o parę słów.

Tymczasem ściskam Pańską dłoń serdecznie oddany

Józef Wittlin [podpis odręczny]

PS. Lada dzień Langerowa ${ }^{8}$ będzie gotowa $z$ tłumaczeniem Borowego ${ }^{9}$ i pośle Panu rachunek. Wykorzystałem u niej 80 centów na każdej stronie.

[Dopisek odręczny długopisem na lewym marginesie:] Jednocześnie piszę do Kuryluka ${ }^{10} \mathrm{w}$ sprawie Odysei ${ }^{11}$.

Maszynopis na kartce formatu A4. List bez koperty, brak daty nadania i adresu nadawcy.

1 Możliwe, iż jest to odpowiedź na list Cz. Miło s za z 11 V 1949 (opublikowany w: Listy do Józefa Wittlina. „Zeszyty Literackie” 2001, nr 3).

2 Chodzi o napisanie artykułu o Emersonie.

3 R. B r and sta ett er w r. 1932 opublikował szkic Legion żydowski Adama Mickiewicza. Początkowo Wittlin chciał, aby podobny tekst Brandstaetter zamieścił w księdze mickiewczowskiej, jednak nie doszło do tego. Korespondencję Brandstaettera z Wittlinem ogłosiłem w „Tematach i Kontekstach" (nr $2\langle 2012\rangle)$.

4 Ludwik Lille (1897-1957) - polski malarz, rysownik i grafik pochodzenia żydowskiego. Studiował medycynę we Lwowie, a w latach 1918-1919 utrzymywał kontakty z czasopismem „Zdrój” (stąd jego znajomość $z$ Wittlinem). W roku 1937 wyjechał na stałe do Paryża.

5 Chodzi o Poemat nielogiczny, ogłoszony w „Kulturze” (1949, lipiec-sierpień) utwór Bronisława Przyłuskiego (1905-1980) - poety, dramaturga i tłumacza, od 1947 r. przebywającego na emigracji w Londynie.

6 Dora Kling beilów na (pseud. Kalinówna; 1905-1986) - polska aktorka teatralna i filmowa. Na początku wojny wyjechała $z$ Polski. Po wojnie osiadła w Rio de Janeiro.

7 Wittlin nawiązuje może do listu Miłosza z 11 V 1949 (późniejszy się nie zachował), w którym poeta przesłał mu wyjątki z pism M. Fuller do Mickiewicza oraz ocenzurowany w Polsce fragment swojego Toastu.

8 Rulka (Róża Maria) Langer (z d. Godlewska) (1906-1993) - urodzona w Warszawie, od 1940 r. zamieszkała na stałe w USA. Pisarka (autorka The Mermaid and the Messerschmitt) oraz tłumaczka bestselerowej w USA książki Z. Ko s s a k-S z c zu cki ej Bez oręża. Tworzyła również teksty dla firm reklamowych. Żona prof. Oskara Langera.

9 Chodzi o artykuł W. B or o w e go Poet of Transformation, który miał być zamieszczony w księdze mickiewiczowskiej.

10 Karol Ku ry lu k (1910-1967) - dziennikarz oraz wydawca, założyciel i redaktor naczelny lwowskich „Sygnałów” (1933-1939) i „Odrodzenia” (1944-1948).

11 Tłumaczenie Odysei Ho m er a dokonane przez J. Wittlin a ukazało się w r. 1924, jego zmieniona wersja - w 1931 roku. Być może, chodzi tu o starania Wittlina o wydanie trzeciej wersji przekładu. Zob. Cz. Mił o s z, list do J. Iwaszkiewicza, z 22 X 1949. W: Zaraz po wojnie. Korespondencja z pisarzami 1945-1950. Kraków 2007, s. 238. Zob. też J. Ko r p a n ty, Zapomniany tłumacz „Odysei” Homerowej. „Przekładaniec” nr 18/19 (2007), s. 192. 
5400 Fieldston Road N. York 63, N.Y.

29 X 1949

Kochany Panie Czesławie,

z przerażeniem donoszę, że Pański list z 27 b.m. ${ }^{1}$ przyszedł pusty, be z pr ze kazu pocztowego na 200 dolarów. Mam nadzieję, że ten przekaz jest gdzieś u Pana, a nawet jeśli przepadł, ma Pan zapewne odcinek potwierdzający wpłatę. Bardzo będę Panu wdzięczny - za doniesienie mi odwrotną pocztą, co się z tym stało i kiedy mogę liczyć na otrzymanie tej forsy.

Co się tyczy Paryża, tzn. Lillego - to jeżeli ma Pan trudności z wysyłką pieniędzy bezpośrednio - to proszę mi dodatkowo przysłać tych, (ile postanowiliśmy?) 20 czy 25 dolarów dla niego. Zawsze ktoś jedzie do Paryża - mógłbym dać, a jeśli nie - to przez bank tutejszy mógłbym posłać. To jest pilne!

[Nazwisko nieczytelne] posłałem już lekarstwa przez konsula Kwietnia, który prosto leci do Polski. Jeżeli on napisze coś do książki - to mu Pan zwróci koszty, a jeśli nie - to będzie to mój prezent dla chorego kolegi.

Dziękuję za adres p. Geralda Sykesa ${ }^{2}$, do którego napisze natychmiast po otrzymaniu tych przekazów od Pana. (Czy można przekazem wysłać więcej czy 100 dolarów?) Zna Pan tłumaczenie tego Sykesa i czy on nie jest drogi?

Dziękuję Panu za miły wieczór spędzony z Panem u nas i za prawdziwą przyjemność, jaką nam sprawił swym Otellem ${ }^{3}$.

Ściskam dłoń i czekam na wyjaśnienie - w sprawie tych 200 dolarów.

Oddany J. Wittlin

Rękopis na kartce białego papieru formatu A4, atrament czarny. List wysłany 29 X 1949 na adres: Mr. Czesław Miłosz / 914 Sheridan Street / Washington, D.C.

$1 \quad$ List Miłosza z 27 X 1949 nie zachował się.

2 Gerald Syke s (1903-1984) - amerykański pisarz, krytyk literacki i wykładowca uniwersytecki. Pracował m.in. dla „The New York Book Review”, „The Nation” i „New Republic”. Tłumaczył z francuskiego. Jego nazwisko nie pojawia się jednak we wspominanej tu pracy o Mickiewiczu.

3 Miłosz przełożył z Szekspira pierwszy i prawie cały drugi akt tragedii Otello. Pierwszy akt ukazał się w r. 1950 w „Twórczości”, drugiego nie ukończył i do przekładów Szekspira już nie wrócił. Zob. A. Romanowska, Szekspir Czesława Miłosza. „Studia Litteraria. Universitatis Iagellonicae Cracoviensis" 2009.

5400 Fieldston Road N. York 63, N.Y.

11 stycznia 1950

Drogi Panie Czesławie,

dziękuję za oba listy ${ }^{1}$. Właśnie przeczytałem Emersona i jestem rad, że Pan to tak dobrze zrobił. W przyszłym tygodniu będzie u mnie p. Sykes, więc dam mu to do 
tłumaczenia i poproszę, żeby przejrzał Pańską angielszczyznę i ewentualnie poprawił, przy czym, jak powiada Wiech, „zaznaczę”, że to Pańskie życzenie. Co się tyczy cytat z samego Emersona - rzeczywiście głupio jest tłumaczyć je z powrotem na angielski, ale czy Sykesowi uda się znaleźć teksty oryginalne?

Teraz - co do Pańskiego artykułu Mickiewicz and Modern Poetry. Uważam, że jest świetny i myślę, że powinniśmy go dać do książki, a jeśli boi się Pan dawać diabła-Eliota, to mógłby Pan łatwo wyrzucić go $\mathrm{z}$ artykułu, co prawda musiałby Pan wyrzucić również cały wywód o „common style” ${ }^{2}$. Ja sugerowałbym taką czystkę: na str. 364 tam, gdzie Pan pierwszy raz używa tego terminu, ująłbym go w cudzysłów i zakończył zdanie: ...,.,Beyond the reach of even the great poets”3. Następne zdania opuściłbym, a zaczałłbym od nowego ustępu: „Mickiewicz attains his effects" 4 - itd. Ewentualnie mógłby Pan parę zdań dopisać. Inteligentny czytelnik amerykański może domyśli [się], kogo Pan cytuje w cudzysłowie, a Pańscy „moczodawcy" oraz inni miłośnicy poezji, socjal-realistycznej, dla których Eliot jest tabu, i tak się nie domyślą.

Rozmawiałem już z Kridlem telefonicznie na temat „Tribune des Peuples” i radziłem dodać jeszcze artykuł o „Miastach robotniczych” ${ }^{5}$. Artykuł Jakóbca ${ }^{6}$ ma już Krzyżanowski $^{7}$ do tłumaczenia, teksty rosyjskie uzupełni razem $z$ Washburnem ${ }^{8}$. Artykuł Washburna jest już u Kridla. Krzyżanowski zapewnia też, że kończy artykuł swój o Cooperze, tak więc naprawdę zbliżamy się do upragnionego końca. Dobrze, że Brandstätter odmówił, gdyż znaleźliśmy specjalistę żydowskiego od Legionu (i romantyzmu polskiego w związku z Żydami), kt[óry] pisze artykuł, oparty na nowszych od Brandstättera materiałach. Jeżeli Kridl dopisze jeszcze uwagi, wyjaśniające poszczególne „człony” (ładne słowo?) książki, będziemy mieli dość bogatą całość.

Miałem list od prof. Noyesa ${ }^{9}$, który oczywiście pozwala wziąć nam ze swego tłum[aczenia] Pana Tadeusza wszystko, czego nasza dusza zapragnie, i jeszcze raz radzi mi w sprawie tłumaczeń wierszem zwrócić się do Haleckiego ${ }^{10}$. Widocznie zacny staruszek nie orientuje się w sytuacji. Co się tyczy honorariów, wkrótce wydam wszystko, co mi Pan posłał przed świętami. Zdam Panu dokładny rachunek. Przewiduję jednak, że będę na te cele potrzebował znacznie więcej. Sam Sykes wziął za swe poprzednie tłumaczenia (59 stron) prawie 200 dol. A teraz mam płacić Krzyżanowskiemu, Washburnowi, Żydom, i znów będzie Sykes.

O tytule pomyślę. Na ogół mam dobre pomysły na tytuły i niejednemu już autorowi poradziłem. Kiedy Pan przyjedzie? Chcielibyśmy wiedzieć naprzód, żebyśmy mogli przygotować rozmowy z drukarnią.

Też nic nie mam od Kuryluka i jak zwykle $z$ braku prądu - wyłączam pracę. Nie wiem, jak można pracować w takiej próżni. Co z Pańskim Otellem? Byłem zachwycony tym, co Pan nam czytał. Wie Pan, że nasza przyjaciółka francuska, kierowniczka kursów dramatycznych w tut[ejszej] École Libre planuje wystawienie na wiosnę ze swymi uczniami Miguela Mañara? Ona w zeszłym roku prześlicznie wystawiła Intermezzo Giraudoux i Polyeucte ${ }^{11}$.

Raz jeszcze dziękuje za Emersona i serdecznie pozdrawiam Pana oraz Jego rodzinę

oddany

Józef Wittlin [podpis odręczny] 
Maszynopis na dwóch stronicach szarego papieru formatu A4. List wysłany 11 I 1950, na adres: Mr. Czesław Miłosz / 914 Sheridan Street / Washington, D.C.

1 Mowa o listach Miłosza z 5 I i 9 I 1950. Listy te poprzedziła jego kartka bożonarodzeniowa do Wittlina z 23 XII 1949, z Waszyngtonu, na której poeta napisał: „Pewnie Pan się zdziwi, ale powiedziałem sobie, że to ostatnie święta Bożego Narodzenia w Ameryce i że już tu dłużej nie wysiedzę, bo jak powiedział pewien szlachcic litewski, który za dużo wypił, mnie nudno”. Zob. Miłos z, Listy do Józefa Wittlina.

2 „Common style” (ang.) - „wspólny styl”. Pojęcie używane przez T. S. Eliota na określenie stylu literatury, w której realizuje się nie geniusz pojedynczego twórcy, lecz geniusz języka. „Common style” przynależy do epoki, w której społeczeństwo osiagnęło moment porządku i stabilności.

3 „Beyond the reach of even the great poets” (ang.) - „poza zasiegiem nawet wielkich poetow”. Oto całe zdanie $\mathrm{z}$ artykułu Miłosza: „But genuine poets are rare, and there periods of history when such an operation is impossible, because of a 'common style' is then beyond the reach of even the great poets".

4 „Mickiewicz attains his effects” (ang.) - „Mickiewicz osiaga swoje efekty”. Artykuł Miłosza świadczy, że zastosował się on do rad Wittlina.

5 Chodzi o nie mający tytułu artykuł wstępny A. Mi c k i e w i c z a do „Trybuny Ludów” (1848, nr 41, z 25 IV). Tekst jest też tytułowany [Osiedla robotnicze]. Zob. A. M i c ki e w i c z, Dzieła. Wyd. Narodowe. T. 12: Trybuna Ludów. W przekł. L. Płoszews kiego. Z objaśnieniami A. Ma u ersbergera. Warszawa 1955, s. 146-148.

6 Marian Jakóbie c (1910-1998) - historyk literatur słowiańskich (rusycysta), profesor Uniwersytetu Wrocławskiego.

7 Ludwik Krzyżanowski (1906-1986) - anglista, tłumacz i działacz polonijny. Od roku 1938 przebywał w USA jako attaché kulturalny i oświatowy w polskich placówkach dyplomatycznych w Chicago i w Nowym Jorku. Po wojnie wykładowca literatury i języka polskiego w Columbia University oraz nauk politycznych w New York University.

8 John Nelson Washburn (1923-2003) - amerykański rusycysta, autor publikacji o Zwiazku Sowieckim.

9 George Rapall N oy e s (1873-1952) - profesor jezzyów słowiańskich w University of California, tłumacz ważnych dzieł literatury polskiej, serbskiej i rosyjskiej na język angielski.

10 Oskar Halecki (1891-1973) - polski historyk, profesor Uniwersytetu Warszawskiego. Od lat czterdziestych XX w. wykładał w uniwersytetach amerykańskich. Był jednym z założycieli Polskiego Instytutu Naukowego w Nowym Jorku.

11 Tragedia P. Corneille'a.

Drogi Panie Czesławie,

dziękuję za recenzję ${ }^{1}$, którą rozpatrzyliśmy wspólnie $\mathrm{z}$ profesorem. We are looking forward ${ }^{2}$ ku Pańskiemu artykułowi biograficzno-historycznemu ${ }^{3}$, tylko prosimy bardzo o szybkie napisanie i ew[entualne] danie go już w tłumaczeniu angielskim. Kridl Panu już o wszystkim szczegółowo napisał. Janta ${ }^{4}$ chce, żeby o nim było w książce w związku z Joshim ${ }^{5}$. Nic dziwnego, skoro przekład ten powstał z jego inicjatywy.

Artykuł o Emersonie tłumaczył Sykes, którego wezwał Kridl na wygawor ${ }^{6}$ i poprawki tłumaczeń $z$ francuskiego. Ja będę musiał zrobić to samo, tylko znacznie łagodniej z przekładami $z$ włoskiego, które skonfrontowałem $z$ oryginałami, znaj- 
dując tylko w kilku miejscach rzeczy rażące. Poza tym uważam je za udane, biorąc pod uwagę fakt, że język włoski jest podobny w skłonności do emfazy - do polskiego, i każdy tłumacz angielski ochłodziłby nieco gorace zwroty stylistyczne. To zrobił, za co trudno na niego się gniewać. Pragnałbym bardzo, żeby książka znalazła się już w drukarni, co w dużej mierze zależy od Pana i od demarszów ${ }^{7}$ Pana w sferach miaro- i dolarodajnych. Skończmy już to, zanim wodorówka nas wykończy. W każdym razie pragnąłbym, żeby książka ukazała się przed r. 1955, czyli przed stuleciem śmierci.

Dziękuję też za forsę, mam nadzieję, że pokryję nią bieżące wydatki, chyba że wyłoni się konieczność nowych tłumaczeń.

Wczoraj odwiedzili nas tu Państwo Markowscy, czyli Terenia Iwaszkiewiczówna ${ }^{8}$ z mężem, który jedzie na radcę poselstwa (ambasady?) do Ottawy. Jadą z Włoch. Uczułem dreszcz starości patrząc na tę dorodną, ukrainną mołodycę, którą znałem mała dziewczynką. On - czy ja wiem? raczej miły.

Kiedy Pan znów tu będzie? Gdybym był bogaty, zaangażowałbym Pana na animatora mego umysłu i jeździłbym z Panem na wycieczki po innych kontynentach. Panu pozostawiam do oceny, która posada bardziej Panu odpowiada, czy obecna, czy ta, którą bym Panu proponował, będąc bogaty.

Przeczytałem już około stu stron Herseya ${ }^{9}$ i raczej mnie to nudzi. Jest tam też wiele naiwności i gaf, jak np. „housewarming party” ${ }^{10} \mathrm{u}$ ortodoksyjnych Żydów, w dodatku za okupacji w getcie. Myślę, że największą zasługą tej książki jest rozpowszechnienie Pańskiego Campo di Fiori, chociażby w tej urywkowej postaci. Może w dalszych częściach książka będzie bardziej interesująca. Ale jak słusznie zauważył pewien mój znajomy, ona nie jest napisana dla mnie, tylko dla ludzi, którzy dopiero po jej przeczytaniu uwierza, że Niemcy mają nie tylko Lidice ${ }^{11}$ na sumieniu.

Ściskam Pana i serdecznie całą rodzinę pozdrawiam

Józef Wittlin [podpis odręczny]

Maszynopis na jednej stronicy szarego papieru formatu A4. List bez koperty. Brak daty nadania i adresu odbiorcy.

1 Miłosz napisał dla Kridla recenzję przygotowywanej książki o Mickiewiczu - zob. Cz. M ił o s z, „Mój wileński opiekun". Listy do Manfreda Kridla (1946-1955): z uzupetnieniem o listy Manfreda Kridla $i$ addendum. $Z$ autografu do druku przygotował, słowem wstępnym, przypisami i nota edytorską opatrzył A. Ka r c z. Toruń 2005. Listy Miłosza do Kridla stanowią ważne uzupełnienie korespondencji między Miłoszem a Wittlinem. Możliwe, że ten list Wittlina jest odpowiedzią na list Miłosza do Kridla zawierający ową recenzję.

2 „We are looking forward” (ang.) - „oczekujemy”.

3 Cz. Mił o s z napisał wstęp do książki o Mickiewiczu, zatytułowany Historical and Biografical Data, który jednak nie został sygnowany jego nazwiskiem.

4 Aleksander Janta-Połczyński w 1940 r. wyjechał z Polski, a od 1945 r. przebywał w Nowym Jorku.

5 Umashanker Jethatal J o s hi (1911-1988) - hinduski poeta i tłumacz. Uchodzi za jednego z najwybitniejszych twórców piszących w języku gudżarati. Karcz (ed. cit., s. 50) wyjaśnia: „Uma Shanker Joshi - wg Stownika pseudonimów pisarzy polskich XV w. - 1970, pod red. E. Janowskiego (Wrocław 1994-1996) jest to pseudonim Maurycego Frydmana (1901-1976), działacza społecznego i oświatowego, wydawcy i inżyniera mieszkającego w Indiach, tłumacza Sonetów krymskich Mickiewicza na język gujarati (1939). Legendę o tym, że był to wybitny poeta hinduski, stworzył Aleksander Janta-Połczyński, patrz: księga mickiewiczowska, s. 274-276”. Przekład ukazał się 
w Ahmedabad, w prowincji Bombaj, ze wstępem Janty. Zdjęcie okładki tej książki zostało też zamieszczone w omawianej pracy o Mickiewiczu.

6 „Wygawor” (z ros. „wygowor”) - „napomnienie”, „nagana”.

„Demarsze” (z fr. „démarches”) - „interwencje dyplomatyczne”.

Młodsza córka Iwaszkiewicza.

9 John Hersey (1914-1993) - amerykański dziennikarz i pisarz, autor kilkunastu publikacji. Wittlin tłumaczył jego Hiroszimę (1946) i napisał do niej wstęp. W liście wspomina natomiast książkę The Wall (1950), poświęconą powstaniu i likwidacji warszawskiego getta.

10 „Housewarming party” (ang.) - spotkanie towarzyskie przy okazji wzięcia w posiadanie nowego mieszkania.

11 Lidice - wieś i gmina w Czechach, położona w powiecie Kladno na północny zachód od Pragi. W czerwcu 1942 po zamachu na Protektora Rzeszy Reinharda Heydricha niemieckie jednostki SS dokonały całkowitej eksterminacji wsi. Łącznie zginęło 340 mieszkańców - mężczyzn, kobiet i dzieci.

Kochany Panie Czesławie,

proszę mi wybaczyć, że dopiero dziś odpisuje - na ostatni Pana list ${ }^{1}$. Znane Panu upały nowojorskie - zawsze odbijają się na moim zdrowiu, które ostatnio jest dość kiepskie, pełno też mam "trabli” ${ }^{2}$ a w wolnych od nich chwilach staram się pracować, żeby pokonać, „die Panik an Ausfahrt” (panikę przy wyjściu) - jak mi raz powiedział Hermann Broch, który zmarł tu nagle w Yale, gdzie był profesorem - parę tygodni temu w 65-tym roku życia. Miał on na myśli panikę ogarniającą artystów w pewnym wieku - do którego Panu jeszcze daleko, Drogi Panie Czesławie. Śmierć Brocha odczułem $b$. boleśnie - był to jeden $z$ ostatnich naprawdę wielkiego formatu pisarzy europejskich, formatu Joyce'a, Prousta, Swena, Virginii Woolf. Od 6-ściu lat stale $\mathrm{z}$ nim korespondowałem i nieraz radził mi w trudnych chwilach.

Trudne chwile! Widzę z Pańskiego listu - że znajduje się Pan w samym sercu kryzysu, jeśli tak wolno się wyrazić - z drugiej jednak strony Pańskie, coraz lepsze artykuły (wczoraj otrzymałem XX Century ${ }^{3} \mathrm{z}$ najlepszymi [tekst nieczytelny]), świadczą o tym, że ten kryzys osobisty - wychodzi na zdrowie Pańskiemu pisarstwu z czego Pańscy przyjaciele - do których się zaliczam z Halusią - szczerze się cieszą. Nie wiem, jak w tej chwili wygląda Pańska sytuacja wizowa, Pańska Pani do nas się nie odezwała. Gdybym miał wrotki - pojechałbym do nich do Washingtonu (w którym w ogóle ani razu nie byłem) - albo żona moja by ją odwiedziła. Nie wiem, dlaczego Pani Janka n a s unika. Więc proszę Pana - o doniesienie nam via Paryż - jak się Pańska rodzina miewa i z czego żyje. Strasznie nie lubię narzekać na zły stan, gdzie trzeba pomóc materialnie lub interwencjonalnie. A niestety obie możliwości dla nas w tej chwili nie istnieją. Profesor K. ${ }^{4}$ też ogromnie przejął się losem Pańskiej rodziny, kiedy mu doniosłem, co mi Pan w ostatnim liście napisał. Z kim w ogóle Pańska Pani utrzymuje kontakt? Czy z tak zawsze Wam życzliwa panią Borowikową ${ }^{5}$ ?

Z ostatniego Pańskiego listu, utrzymanego w tonie rozpaczy, widzę, donosi mi on (cytuję dosłownie: „trzeba nam szczerze istnienia, a zupełna samotność może nawet tytana 〈którym nie jestem〉, doprowadzić do obłędu”) - że nerwy Pańskie 
rzeczywiście nie są świetne, czemu się nie dziwię. Ale chciałbym skorzystać z przywileju podwójnego starszeństwa i w latach życia, i w latach emigracyjnej samotności - żeby Panu powiedzieć coś o niej. Uczynię to zresztą również z myślą o Panu w najbliższym artykule dla „Kultury” - tu chciałbym jednak zwrócić Pańską uwagę, że nie jest Pan sam i nie jest Pan pierwszym emigrantem, że musi Pan, zerwawszy z tamtym światem fałszywego „my”, my - używanego pod terrorem, potępiającym wszelkie ,ja" - poczuje się solidarny z wszystkimi samotnikami, z których jednym z najlepszych był właśnie wspomniany Broch. Jego Śmierć Wergilusza [to] mimo wszystko typowo niemieckie wady (gadanie na „dubelt” 6 od czego nie jest wolny nawet Tomasz Mann), nie mogłaby powstać w innych warunkach, tylko w emigracyjnych.

Mój nieodżałowany wielki przyjaciel Joseph Roth ${ }^{7}$ też był emigrantem. W końcu - zapomniał Pan, że biadając nad swoim przyszłym losem mam na myśli oczywiście jedynie literacki los - że pisał Pan to do człowieka, który gorzej niż inni polscy pisarze emigracyjni znosi ten los, gdyż z faktu emigracji nie zrobił sobie ani

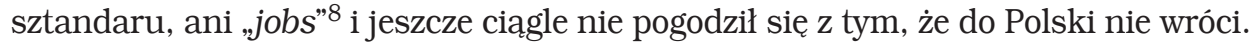
Do Polski - w której - jako obywatelowi II g i e j [!] klasy właściwie nigdy mi dobrze nie było. 10 lat mego pobytu w Ameryce - to 10 lat straszliwego wyjałowienia - a le wyłącznie z mojej własnej winy, Drogi Panie Czesławie. Staram się obecnie tych 10 lat przekreślić i odrobić i Bóg jeden tylko wie, czy mi się to uda. Gdyż jestem w wieku, w którym więksi od nas - Balzac, Szekspir, Molier, Dante już nie żyli. A ja osobiście jestem jak najgorszym przykładem tego, co emigracja Z człowieka może zrobić. Ale jak powiedziałem - inni są silniejsi i podciagnęli się - a nawet odrodzili. Weź Pan Lechonia np. Ostatnio pisze - moim zdaniem piękne rzeczy - oczywiście na miarę swych możliwości. Jemu np. bieda dobrze zrobiła - a gdy żył w dostatkach ambasadowych - w ogóle nie mógł pisać lub pisał słabo. Mówiąc o emigracji pozytywnej - mam tu na myśli przede wszystkim Niemców, - którzy sa - godni podziwu. Wymienię w moim artykule wszystkich mniej więcej, których znam. Hiszpanie na emigracji też dobrze funkcjonują. Taki R[nieczytelne] np., Ortega y Gaset lub Salvador de Madariaga właściwie na emigracji zakwitli. Nie bój się Pan, Drogi panie Czesławie - samotności - w tak dobrym towarzystwie. Przecież i w „Figarze” Pana czytałem i o tym doskonałym XX Century. Mam przekonanie, że Pan nie tylko da sobie radę, ale że swoim osobistym czarem powiększy Pan liczbę i tak wielu przyjaciół, którzy Panu pójdą na rękę. Gwizdnij Pan na te panienki w Polsce, które Pana wielbiły, te same panienki będą więcej wielbiły Pana - jeśli Pan n i e b ę d zi e pisał w Kraju. A zresztą, czy nie zależy Panu więcej na panienkach, z którymi Pańscy synowie będą romansowali, niż na tych, co do Pana puszczały oko? Bo mnie najwięcej już zależy na tym, żeby dzieci mojej córki i kiedyś dzieci tych dzieci mnie czytali. 30 lat temu, mnie też panienki we Lwowie przynosily kwiaty, ale dużo dałbym za to, żeby na mój grób (gdzie on będzie?) przychodziła całkiem nieznana mi młodzież. Ot, proszę wybaczyć staremu - te korektury perspektywiczne. Życzę Panu przede wszystkim zdrowia, żeby Pan mógł wytrzymać k a ż da przykrość - i czekam na parę dobrych wieści od Pana zawsze Panu szczerze oddany

Żonie Drogiej wiele serdeczności. 
Rękopis na dwóch stronicach niebieskiego papieru firmowego połączonego z koperta. List wysłany 19 VII 1951 na adres: France / Mr. Czesław MIŁOSZ / c/o „KULTURA” / I. Av. Corneille / MAISONS LAFFITTE (Seine et Oise).

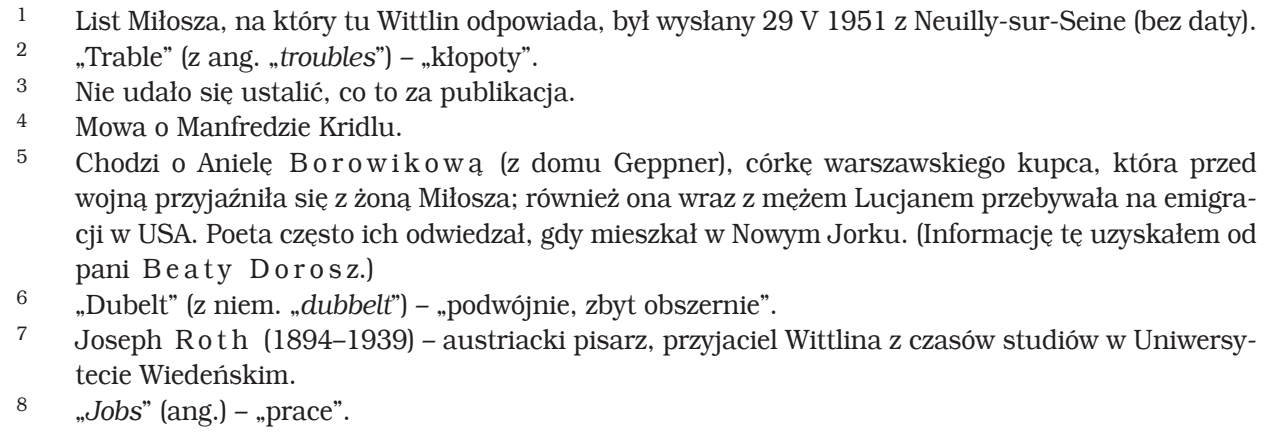

Kochany Panie Czesławie,

dziękuję serdecznie za list ${ }^{1}$, na który od dawna czekałem. Bardzo się martwiłem tak długim milczeniem Pańskim, tym bardziej że nasza ostatnia rozmowa telefoniczna przed Pańskim wyjazdem - trochę mi ciążyła - jako może nie bez wpływu na Pańską decyzję. Pamięta Pan tę rozmowę? Tak czy owak serdecznie żal mi Pana, lecz mam nadzieję, że prędzej czy później Pana tu zobaczymy. Oby - prędzej. Ma Pan bardzo oddanych przyjaciół, którzy z pewnością zrobią wysiłek, aby Panu pomóc w połączeniu się z rodziną. Doskonale wczuwam się w Pańskie położenie, gdyż byłem w podobnej sytuacji w r. 1939-1940, kiedy ja byłem w Paryżu, a moja rodzina w Polsce, pod niemiecką okupacją. Dobrze, że Pan pisze, gdyż jedynie praca chroni nas od rozpaczy. Nie wiem, czy ten list będzie wcześniej w Paryżu od p. J. Czap[skiego], którego niestety raz tylko tutaj widziałem. Pisze go chaotycznie - aby nawiązać z Panem kontakt i zapewnić, że zarówno moja żona jak i ja - kiedy tylko możemy - staramy się wytworzyć przyjazną atmosferę dokoła Pańskiej osoby, twórczości, sprawy przyjazdu tutaj. P. Czap[ski] opowie Panu, jakie tu są nastroje, gdyż zna je lepiej ode mnie. Pamięta Pan - jak 17 VIII 1950, gdy Państwo wyjeżdżali od nas, wspominałem, że może spotkamy się w Paryżu - u Józia Cz[apskiego]. Zabawne, co? A także jest Pan w „Kulturze” drukowany wcześniej - ode mnie. À propos: proszę zapewnić pana Giedroycia, że za parę dni przyślę mu „profilaktyczną obronę" Gombrowicza ${ }^{2}$ do lipcowego numeru. Nie piszę do niego wprost, gdyż wstyd mi pisać do człowieka, który od tylu lat czeka na moje rzeczy do „Kultury” i nie machną na mnie ręką. Ten jego wieczny upór, będący zapewne „token”3 estymy, naprawdę mnie wzrusza i dodaje otuchy. Ale wróćmy do Pana. Zaraz po pierwszym telefonie Józia Cz[apskiego] napisała moja żona do Pańskiej Pani - b. ciepły list - upłynęło już ponad 3 tygodnie, a Pani Janina nie zareagowa- 
ła. W ogóle - jej milczenie - nie wiedzieliśmy, jak interpretować. O ile wiem, i Hertzowie do niej pisali, a wczoraj profesor wziął ode mnie adres. Swoją drogą, jego rola jest teraz „peculiar" więzy Pańskimi dawnymi chlebodawcami. Chlebuś ten, co prawda, zawsze wydawał mi się zakalcowaty. Drogi Panie Czesławie, Pański artykuł zrobił tu na wielu ludziach dobrej woli i dobrej inteligencji - b. dobre wrażenie, - wiersze i tak bez akompaniamentu tego artykułu - działają pierwszorzędnie. Ja te wiersze już znałem, niektóre przysłał mi Pan przecie w rękopisie i nie muszę Pana zapewniać - o moim do nich stosunku.

Winszuję najserdeczniej w żony i we własnym imieniu powtórnego ojcostwa ${ }^{5}$ i z całego serca, żeby Pan mógł osobiście cieszyć się pierwszymi zą̧kami wtóro-rodnego dziedzica. Przesyłam Panu program z przedstawieniami misterium Pańskiego stryja ${ }^{6}$ - grali amatorzy: amerykańska młodzież (przeważnie) izraelskiego pochodzenia, a grali świetnie. Nasza przyjaciółka, kierowniczka tych francuskich „młodzieżowych” (piękne słowo krajowe!) teatrów pani Daniel, znała Oskara Miłosza i grała w teatrze Vieux Colombier rolę Girslany w Miguelu Mañarze ${ }^{7}$. Marzy ona o tym, żeby Pana poznać, jak Pan przyjedzie, zaprosimy Pana z nią. Nie watpię, że to nastapi, że trudności będą pokonane. Żałuje, że nie mam stosunków odpowiednich w sferach decydujacych o wizach dla takich ludzi jak Pan. Sam jestem nie całkiem koszerny - bo moja żona pracowała na ten nasz zakalec - - ale dużo zależy od urobienia opinii wśród rodaków, żeby nie. A to czynimy gorliwie. Zwłaszcza głupotę trudno zmiękczyć, no i przyrodzoną zawiść Kalibanów ${ }^{8}$ - do Angolów.

Niech Pan będzie dobrej myśli i pisze swoją książkę spokojnie. Tu nie najweselej, ale jak się jest w Pańskim wieku - można przezwyciężyć smutki łatwiej i zrobić $\mathrm{z}$ nich piękne wiersze. Tylko mnie już się zaczyna "finesta senectus" ${ }^{\text {, }}$ może przedwczesna, ale bardzo dokuczliwa. $Z$ egoistycznych względów też pragnę Pańskiego przyjazdu do St[anów] Zj[ednoczonych] - zawsze w Pańskim towarzystwie czułem się odmłodzony umysłowo i język mi się rozwiązywał.

Starość! Słyszał Pan o tym, że nasza córka w lutym wyszła za mąż - za młodego inż. Liptona, syna tej pani, która miała „Librairie Lipton” na Lexington Ave. Pani Germaine Lipton zna Pana $z$ księgarni, którą sprzedała rok temu, a obecnie pracuje w piśmie „France-Amerique” ${ }^{10}$. Mój zięć jest b. miły, poważny chłopak, interesuje się matematyka, muzyką i antropologia, poza tym buduje szosy w stanie N[ew] Yersey [!]. Młodzi mieszkają w New Brunschwick i rzadko tu przyjeżdżają. Pośpieszyła się smarkula i może mnie niedługo dziadkiem zrobić. Smutno bez niej w domu, gdzie tylko kotka reprezentuje element niewinności.

Panie Czesławie, kiedy będziemy się razem śmiali? Tak lubię Pański śmiech. Przeczuwam, a moje przeczucia na ogół się sprawdzaja, że niedługo się zobaczymy, przy czym ja do Francji się nie wybieram. Mnie raczej ciągną Włochy, i Kraj, i ludzie, i sztuka.

Proszę do mnie pisać częściej - sprawi nam Pan tym dużą przyjemność - a żonie proszę łaskawie napisać, żeby się do nas odezwała. Słyszę, że materialnie jakoś daje tam sobie radę. To przynajmniej dobrze.

Ściskam Pana serdecznie i pozdrawiam w imieniu żony 
PS. Proszę ugłaskać Giedroycia. 3 rzeczy mam dla niego na „warsztacie"11 przez Gombrowicza.

Rękopis na szarym papierze listowym, atrament czarny. List wysłany 9 VI 1954 na adres: France / Mr. Czesław Miłosz / To Mr. Jerzy Giedroyć, „Kultura” / MAISONS-LAFFITTE (S. et O.) / 1, Av. Corneille.

1 Ten list Wittlina poprzedziły przynajmniej cztery listy Cz. Miło s za. Zachowały się trzy: z 21 III 1950, 29 V 1951 oraz 4 XI 1952 (zob. Listy do Józefa Wittlina). Nie zachował się natomiast list, na który odpowiada tu Wittlin.

2 W „Kulturze” z 1951 r. (nr 7/8) ukazał się artykuł J. W it tl in a Apologia Gombrowicza, o którym wspomina on w liście.

3 „Token” (ang.) - „znak”, „dowód”.

„Peculiar” (ang.) - „szczególny”.

Mowa o drugim synu Miłosza, Piotrze, który urodził się w 1951 roku.

6 Chodzi o Oskara Miłosza - spokrewnionego z Czesławem Miłoszem poetę i dyplomatę litewskiego, mieszkającego w Paryżu.

7 Miguel Mañara-dramat misteryjny O. Miłos za.

8 Kaliban - brutalny, półdziki niewolnik o odrażającej powierzchowności, postać z Burzy W. Sz e kspira.

9 „Finesta senectus” (łac.) - „wiek sędziwy”.

10 Czasopismo poświęcone Francji, założone w 1943 r. w USA. Ukazuje się do dziś.

11 Nie wiadomo, o jakie trzy teksty chodzi. Wittlin wielu utworów nie ukończył.

Drogi Panie Czesławie,

proszę mi wybaczyć, że dopiero dziś dziękuję Panu serdecznie za Traktat poetycki. Czynię to po trzykrotnym przeczytaniu. Rzecz imponująca, w treści, konstrukcji i wyrazie, chociaż, moim, bardzo skromnym, zdaniem, nierówna, jeśli idzie o ingrediencje. Być może jednak, że nie zrozumiałem wszystkiego, zwłaszcza ostatniej części, tak jak należałoby ją rozumieć. Jest to oczywiście moja wina. Grunt, że pozostaję wciąż pod działaniem czarów, które Pan w tym „traktacie” zgromadził, zwłaszcza $\mathrm{z}$ wielką ,force évocatrice” ${ }^{2}$ namalował Pan „Piękne czasy”, czasy mojej młodości. Strofy poświęcone okupacji, powstaniu warszawskiemu, gettu najbardziej mnie „wzięły”. Zawsze, ilekroć Pan dotyka tych spraw, bije Pan w struny z szlachetnego metalu, podobnie jak w fragmencie Antygony, który z entuzjazmem „opracowałem" w moim miesięcznym Programie literackim ${ }^{3} \mathrm{z}$ aktorami. Antygonę mówiła Modzelewska ${ }^{4}$, Ismenę Zelwerowicz-Orchoniowa ${ }^{5}$. Nie powiem, żeby wykonanie było na najwyższym poziomie, ale to wina aparatu technicznego i szczupłości wydzielonego aktorom czasu. Zaledwie - dwie próby. W tym programie, który prowadzę już przeszło dwa lata, kilka razy nagrywaliśmy Pańskie wiersze M. ${ }^{6}$ i Kolędników. W wyborze muszę kierować się nie tylko własnym smakiem i upodobaniem, ale i warunkami głosowymi i talentowymi wykonawców, którymi rozporządzam, a także względami radiofonicznymi. W niedalekiej przyszłości spróbuję dać fragmenty z Traktatu poetyckiego właśnie. W związku $\mathrm{z}$ łaskawą dedykacją na egzemplarzu, który mi Pan przysłał, a mianowicie $z$ aluzją do Anny $\mathrm{Csillag}^{7}$, pozwalam sobie przypomnieć Panu cały wiersz, który napisałem o niej, jeśli to jest tylko o niej. 
Wiersz ten był napisany w r. 1934, drukowany w „Wiadomościach Literackich”, dedykowany Toli Korian ${ }^{8}$, która go często wykonywała na estradach przedwojennych, głównie IPS'u ${ }^{9}$. Piękną muzykę do niego napisał Palester ${ }^{10}$. Był przedrukowany w Antologii emigracyjnej Lama ${ }^{11}$ i może go Pan tam widział. Niemniej przepisuję go Panu.

Wracając do Traktatu poetyckiego, zadziwia mnie u Pana fascynacja Ameryka, której ulega Pan we Francji. Podobnie jak zadziwia mnie u Pana fascynacja najnowsza poezją amerykańską. U mnie - na odwrót. To, że przeszło 16 lat już nie byłem w Europie, oddziaływa paraliżująco raczej na pozytywną percepcję miejsc, w których tkwię - bez wielkiego entuzjazmu. Nie uległem też magii tego kraju, którą Pan tak żywo i świeżo wyraził w ostatniej części poematu. Może dlatego, że bardzo niewiele widziałem z Ameryki. Nie uwierzy Pan, że do tej pory nie byłem nawet w Waszyngtonie. Wybieram się tam jednak w jesieni. Wracając do poezji amerykańskiej, którą Pan zna jak mało który nie-Amerykanin, chciałbym Pana zachęcić do udziału w Antologii Pawła Mayewskiego ${ }^{12}$, mającej wyjść w „Criterion Books”. Mówił mi Mayewski, że czeka na decydującą odpowiedź Pana. To bardzo uroczy, utalentowany i bystry młody (ma 36 lat!) człowiek. Ma za sobą łagry, wojsko, Anglię, gdzie ożenił się z czarującą Angielką, pisze przeważnie po angielsku, opowiadania i powieści, w których "l'esprit concentrationnaire"13 włada pośrednio i bezpośrednio. Opowiadania jego były drukowane w magazynach „New World Writing” i „Modern Writing”. W najbliższym numerze „Paris Review” ma być jego nowela. Bardzo go lubię. Jest to człowiek niezwykle delikatny, ale lubi pisać rzeczy bardzo „hard boiled"14. Czasem mu się udaje. O nas niewiele mogę Panu powiedzieć, co by Pana zajęło. Czekam z dnia na dzień ukazania się mego przekładu Odysei w nowej wersji. Gdy wyjdzie, każę Panu wysłać egzemplarz wprost $z$ Londynu, w nadziei, że Pan to przeczyta. Pamięta Pan, jak pewnego wieczora u nas czytałem Panu I pieśń tej wersji, a Pan nam mówił z pamięci urywki Swojego przekładu Otella?

Bardzo mi żal biednego prof. Kridla. Męczył się długo, ale zdaje się do końca nie wiedział, że to rak. Ściskam Pana serdecznie, Pani rączki całuję, całuję Pańskich synów. Halina pięknie się kłania.

\section{oddany Józef Wittlin [podpis odręczny]}

Maszynopis na papierze formatu A5, list bez koperty. Do listu dołączony maszynopis wiersza À la recherche du temps perdu.

1 Nie zachował się list, na który odpisuje tu Wittlin. Ostatni zachowany list Miłosza przed ta odpowiedzią pochodzi z 1955 r., a wysłany był z Paryża, ostatni zaś zachowany jego list do Wittlina ma datę 7 VI 1957 - zob. Listy do Józefa Wittlina.

2 „Force évocatrice” (fr.) - „siła ewokacyjna”.

3 Wittlin prowadził w Radio Wolna Europa m.in. audycję Program literacki.

4 Maria M o d z el e w s ka (1907-1997) - aktorka filmowa kina niemego i dźwiękowego. Jedna z najwybitniejszych aktorek teatralnych przed drugą wojną światową. Od roku 1939 na emigracji, głównie w Stanach Zjednoczonych.

5 Helena Zelwe rowicz-Or c hoń (1903-1998) - aktorka i pedagog, znana ze swej działalności na rzecz propagowania kultury polskiej za granicą. Po wojnie na emigracji - najpierw w Londynie, a potem w Nowym Jorku.

6 Nie jest jasne, co oznacza litera „M”.

7 Fikcyjna postać kobieca z przedwojennej reklamy maści na porost włosów, mająca bardzo długie włosy, które rzekomo zawdzięczała używaniu tej maści. Wittlin napisał wiersz À la recherche du temps perdu dedykowany Toli Korian, którego bohaterką jest Anna Csillag. 
8 Tola Korian, właśc. Antonina Terlecka z d. Kopczyńska (1911-1983) - polska aktorka, pieśniarka oraz pedagog. Żona Tymona Terleckiego. Od początku drugiej wojny światowej przebywała na emigracji w Londynie.

9 Instytut Propagowania Sztuki - instytucja utworzona w 1930 r. z inicjatywy artystów i historyków sztuki, w celu propagowania nowoczesnej polskiej sztuki. Siedziba IPS, wybudowana i otwarta w r. 1931, mieściła się w Warszawie.

10 Roman Palester (1907-1989) - polski kompozytor od 1947 r. przebywający i tworzacy na emigracji. W latach 1952-1972 mieszkał w Monachium i pracował jako kierownik działu kulturalnego polskiej sekcji Radia Wolna Europa. Zmarł w Paryżu.

11 Stanisław Lam w czasie drugiej wojny światowej mieszkał we Francji; był wówczas również więziony w obozach hitlerowskich. Od roku 1944 sprawował funkcję kierownika Księgarni Polskiej w Paryżu. Wydał książkę Najwybitniejsi poeci emigracji współczesnej. Antologia (Paryż 1951).

Paweł Mayewski (1921-1991) - autor opowiadań, uczestnik kampanii wrześniowej i więzień sowieckich łagrów. W liście mowa jest o książce Czas niepokoju. Antologia wspótczesnej poezji brytyjskiej i amerykańskiej (New York 1965).

„L'esprit concentrationnaire” (fr.) - „atmosfera obozów koncentracyjnych”.

14 „Hard boiled” (ang.) - bardzo poważne (dosł. „ugotowane na twardo”).

Kochany Panie Czesławie, drogi „wyrodku”!

Niewątpliwie istnieje telepatia. W ostatnich dniach dużo o Panu musiałem myśleć i chciałem do Pana napisać, ale ubiegł mnie Pan przysyłając Prywatne obowiazki oraz angielskie eseje ${ }^{1}$. - Bardzo serdecznie dziękuję za miła pamięć. A swoją drogą - paczka, którą mi Pan wysłał 3 marca, przyszła 15 marca - i dlatego dziś drogiemu Panu dziękuje. Jeszcze zanim ja otrzymałem - dostałem Prywatne obowiazki wprost od Giedroycia - jak wszystkie Pańskie książki wydane przez niego. Więc chciałem do Pana napisać, aby Mu powiedzieć, jak bardzo ta książka przypada mi do smaku, podobnie jak Pańskie wiersze drukowane w ostatniej (styczeń-luty) „Kulturze”. Już przedtem chciałem do Pana pisać - aby Mu to powiedzieć, że ja od lat czytuję po grecku - i cieszę się, że Pan zasmakował w tej lekturze.

Ja tu jestem „wyrodkiem”, z tą różnica, że Pan ma dosyć siły, aby ten status znosić, więcej: to „wyrodkostwo” jest jednym z źródeł Pańskiej siły i pozwala Panu na ustawiczne odnawianie się i świeżość - z czego my, czytelnicy $z$ wdzięcznością korzystamy. Moje wyrodkostwo raczej osłabia mnie i nakazuje (ale właściwie po co mówić w czasie teraźniejszym?) - ostrożność, niekiedy aż zanadto rozwiniętą. Ale nie chcę mówić o sobie.

À propos "wyrodków” takich jak Pan: nie byłoby bez nich uczciwej literatury. Ogromnie wzrusza mnie Pański stosunek do biednego Wata - jego poezji - zasługującej na szerszy odbiór - niż to się obecnie dzieje. Ale gdzie szukać odbiorców tej poezji? Na emigracji - czy w kraju? Bardzo ciekaw jestem i czekam na ten pamiętnik Wata, czy jak to nazwać - który Pan z takim poświęceniem nagrał na taśmę i zamierza ogłosić ${ }^{2}$.

Kochany Panie Czesławie! Pięknie, że przypomniał Pan sobie mnie, nie widzieliśmy się już sporo czasu - ostatnio chyba w Paryżu, spotkaliśmy się w kawiarni 
razem $\mathrm{z}$ Watem - a innym razem znowu w Paryżu - w hotelu, gdzieśmy mieszkali. Proszę Pana bardzo - o dalszą, życzliwą pamięć - a jeśli Pan będzie w N[owym] Jorku - o odwiedziny. Niedomagam od dłuższego czasu i muszę pogodzić się ze starością. To żona Aleksandra H. ${ }^{3}$ powiedziała, że właśnie to jest „a full time job” 4 . Bardzo trafna maksyma.

Ma Pan tu goracego wielbiciela w osobie młodego Jana Gólickiego ${ }^{5}$ - który mimo małej brody jest jeszcze trochę zielony. Ale lubię go, bo jest inteligentny, bystry i dobry człowiek. Ma czarującą żonę. Zapewne wróci stąd na dwa lata do Z. ${ }^{6}$ Co Pan o nim sądzi?

Czy widuje Pan w Berkeley moją siostrę? Ona od pewnego czasu choruje i widujemy się rzadko. Ostatnio prosiłem ją w liście, żeby wyraziła Panu - mój zachwyt nad Pańskimi nowymi wierszami.

Proszę Pana bardzo o kontakt. Oboje $z$ Haliną, jak zawsze, zapraszamy, wspominamy Pana serdecznie i serdecznie Pana i Pańska Panią pozdrawiam od siebie i od niej.

\title{
Dłoń Pańską ściskam
}

\section{Józef Wittlin}

Rękopis na dwóch stronicach białego papieru listowego formatu A4, z nadrukiem u góry: „Joseph Wittlin 5400 Fieldston Road New York. N.Y. 10471”. List wysłany 19 III 1972 na adres: Profesor Czesław Milosz / Dept. of Slavic Languages and Literature / University of California / BERKELEY, Calif. 94720.

1 Jest to odpowiedź na otrzymaną od Miłosza przesyłkę z książkami. Nie wiadomo, czy przesyłce towarzyszył jego list.

2 Mój wiek - dwutomowy „pamiętnik mówiony” nagrany przez A. Wata z pomocą Cz. Miłos za podczas pobytu Wata w Berkeley w latach 1963-1964.

3 Chodzi zapewne o Aleksandra H e r t za (1895-1983) - polskiego socjologa żydowskiego pochodzenia, od 1940 r. na emigracji w USA. Współpracował on z Instytutem Literackim „Kultura”. Wydał m.in. klasyczne dzieło Żydzi w kulturze polskiej (1961).

$4 \quad$ „A full time job” (ang.) - ,praca na pełny etat”.

5 Nie udało się ustalić, kim był Jan Gólicki.

6 Nie jest jasne, co oznacza litera „Z”.

Abstract

\section{JÓZEF WITTLIN'S LETTERS TO CZESŁAW MIŁOSZ}

\author{
Edited by \\ RYSZARD ZAJĄCZKOWSKI John Paul II Catholic University of Lublin
}

Józef Wittlin and Czesław Miłosz's correspondence evidences the life emigrants. The letters are a complement to Miłosz's letters to Wittlin published earlier. Most intensive contacts of the writers is observed in the 1940s and 1950s, when Miłosz served for Polish diplomacy in the USA. It was the time when they most frequently exchanged letters and cooperated in the publication of the book Adam Mickiewicz. Poet of Poland. A Symposium (New York 1951). There is no output of their correspondence dated 1960s, though we cannot exclude their telephone contact at that time. Both Miłosz and Wittlin respected each other's creativity, yet they did not feel much reciprocal affinity. They differed as regards political views and life situation. Wittlin in his letters to Miłosz was fairly official and undemonstrative, which may be well visible in comparison to his letters to Wierzyński, Haupt, Giedroyc, and even Kridl. Even so, their correspondence is important evidence of contact and cooperation of the writers-vital not only for Polish literature. 